\title{
Exploring the Transformation Strategies of Servitization: Cases of Large Manufacturing Firms in Taiwan
}

\author{
Hung-Chia LIN ${ }^{1, a}$, Wen-Hong CHIU ${ }^{1, b,{ }^{*}}$, Chien-Yu LIN ${ }^{1, c}$, Shieh-Liang CHEN ${ }^{1, d}$ \\ ${ }^{1}$ Department of Business Administration, Asia University, Taichung, Taiwan \\ ahongjia@cht.com.tw, bandychiu@asia.edu.tw, ca04375285962941@yahoo.com.tw, \\ peterrchen@asia.edu.tw \\ ${ }^{*}$ Corresponding author
}

Keywords: Servitization strategy, Manufacturing industry, Servitization of manufacturing.

\begin{abstract}
This study proposes value-added servitization strategies, differentiation servitization, expansion servitization, and integration servitization based on the depth and breadth of servitization. This study selects 58 domestic manufacturers among the top 100 Taiwanese manufacturers as subjects and collects 271 transformation events. The findings are described as follows:1. Manufacturers adopt investing in cross-industry service and vertical integration of the supply chain as their priority among different strategies; 2 . Derivative cross-industry service, vertical integration of the value chain, web platform service, and technical service become the development trends of manufacturers; 3. Market/end-user service, agency service, image promotion service, cross-industry support service, and green service are easily ignored by manufacturers; 4 . Computer peripheral of information and communication technology service and the electronics industry show fewer instances of transformation, while the computer system industry shows more instances of transformation; 5. Manufacturers generally incorporate vertically integrated companies outside their industry and offer system platform to serve the customers by investing service.
\end{abstract}

\section{Introduction}

In the past, a clear divide existed between the manufacturing industry and the service industry in Taiwan. However, due to a change in the environment, the impact of globalization, the manufacturing industry can no longer just focus on just their industry. Instead, they need to adapt to the changes. In 2010, MOEA pointed out that the financial crisis caused worldwide recession but also brings about opportunities for industries to transform and reconstitute themselves. However, when manufacturers see the opportunities and would like to cross industry boundaries and enter the field of innovation service, they find that they do not have an effective method that can help businesses smoothly transform themselves and join the ranks of " 2.5 industry." Existing literature shows that case studies are mainly studies on industry transformation, operating strategies and models, and development details of servitization of the manufacturing industry. There are seldom substantive strategy contents that study the servitization of the manufacturing industry in instigating the transformation of the manufacturing industry. To summarize the discussion above, we see that how the manufacturers seek new operational models and by what method they cross over their own industry's boundary are topics that should not be ignored in servitization of manufacturing in the future. This study will investigate: (1) Investigating which servitization strategies are used in the transformation of the manufacturing industry; (2) Investigating manufacturing servitization strategies to grasp future trends; (3) Investigating whether there are universally applicable services in the servitization of manufacturing. I will compile an effective transformation strategy for reference by readers with three viewpoints transformation strategies, depth of servitization, and the direction of development - as well as through case studies.

\section{Literature Review}

\section{Industry transformation}

Transformation means making significant changes in terms of organization and structure, such as the mission of the organization, goals, structure, and corporate culture. It is seen as a second order 
change, which is an organization change that is multi-dimensional, multi-level, qualitatively defined, non-continuous, and logically leaping organization change. Define "corporate transformation" as rethinking and evaluating traditional functional organizational structure. Horizontal process flow of a business is seen as the back bone of management. It will result in improvements that are great leap forwards. REF [7] [4] define it as follows: "Transformation is the shift of the whole organization in terms of values, styles, attitudes, skills, and behavior so that the organization can respond to various changes in the environment in time." And its most important goal is: "A business can greatly improve competition results after a period of effort and continue to maintain the competitiveness of the business. [12] [2]".Transformation is classified as "industry transformation";"market transformation"; "business transformation";"'operational transformation". Based on the above descriptions, this study believes that business transformation is an organizational change made in order to allow the organizational structure to adapt to external changes in the environment, after a business has been operating for a period of time and encounters a bottleneck in operation. Moreover, different businesses face significantly different problems. Therefore, there is no good or bad transformation, only suitable or not suitable transformation.

\section{Servitization}

Servitization means that the role of a manufacturer evolves from the supplier of objects to the supplier of services. It is a dynamic evolution process. The business and products may be in the process of servitization. The issue is from the viewpoint of value chain, meaning that manufacturers expand the scope of service to their customers downstream [16] [18] [3] [8] [11] . That the following three factors are strategies for product-oriented companies to begin using service strategies: outsourcing trends, customers purchasing equipment to be installed are almost saturated, and the mass commoditization of the market for the product [1] [17]. Based on the discussions above, this study believes that servitization of manufacturing is instigating market evolution and outsourcing trend of products and services from the position of customers by new core competencies and platforms, new pricing models and revenue models, and technology innovation by the extension of industry value chain.

\section{Integrated servitization strategy}

Department of Industrial Technology, Ministry of Economic Affairs points out in its research that servitization of the manufacturing industry can be divided into three levels: "Enhancing customer value starts from serving the customers. Aside from offering 'manufactured' products, the business will also offer diversified value-added service so that the business can improve customer satisfaction and increase the core competitiveness of manufacturers"; "Extending manufacturing value: businesses develop service products from their manufacturing advantages or derive new service business from there"; and "Forward-looking application of service oriented products -oriented products: on the foundation of offering 'service' with innovative value to customers and lead domestic manufacturers to develop new products." In sum, this study consolidates the model structure of manufacturing servitization mentioned above and summarizes the two manufacturing servitization depths, which are low-level servitization and high-level servitization. Product servitization is mainly a transition from product orientation to service orientation. It does not use selling products as its main operational model. Rather, it uses "service" to produce differentiation and innovation of technology to produce higher added value [17] [9].

This study produces four strategy viewpoints based on the breadth of transformation and the extent of servitization with three viewpoints in transformation strategy, the extent of servitization, and the development direction of servitization. Strategy 1: With product-oriented concept, the business develops from tangible products to intangible services. Transformation is service-oriented, without expansion across industries; Strategy 2: The manufacturer does not simply offer tangible products to consumers. Rather, it uses new core-competence/platform as a viewpoint and uses the unique core competence of the business as the foundation to offer extension service or supply chain integration that is hard to replace in order to satisfy the demand from consumers, and the business focuses on the 
current condition of that industry; Strategy 3: When core capacity of the service department of the manufacturer climbs to a certain extent, with internal technological innovation and receiving external technology, or while undergoing corporate restructuring doe to strategic concerns of the business, the manufacturer will restructure, spin-off, or invest in subsidiaries with existing capital to provide service to clients; Strategy 4: With derivation from the supply chain, new industry categories, new value assertions, new pricing models and revenue models, the business offers service to upstream and downstream of the value chain and new pricing models and revenue models.

\section{Method}

This study uses case study method [19]. First, in terms of the breadth of transformation (the vertical axis) transformation across industry boundaries are mainly transformations across industries in new industries and new business entities. The transformation of individual industry focuses on individual industry and does not involve in other industries. Second, in terms of the depth of servitization (the horizontal axis). The four servitization strategy viewpoints based on the breadth of transformation and the extent of servitization with three viewpoints in transformation strategy, the extent of servitization, and the development direction of servitization: (1) Value-added servitization strategy (strategy 1); (2) Differentiation servitization strategy (strategy 2); (3) Expansion servitization strategy (strategy 3); (4) Integration servitization strategy (strategy 4). This study adopts case incidents to study the four servitization viewpoints and their influences on one another and the connection between themselves, so that businesses can find support when they are faced with the task of transformation.

\section{Cases}

There are four criteria for selecting cases for this study. First, the business has high name recognition and is in the position of an industry leader; Second, there is an incident of actual transformation in servitization with the business; Third, a real example of the impact of that case on the entire industry can be traced; Fourth, the research selects businesses with long histories, a rich collection of data-worthy incidents, and high media attention among the top 100 manufacturers in Taiwan ranked by revenue. Then, data within the past ten years (2004-2013) from UDNdata on the manufacturing industry will be drawn from, and exclude 22 businesses that underwent transformation without significant incidents clearly related to servitization and with little information available. Examples of conglomerates include 20 businesses such as Foxconn, ChiMei Optoelectronics, Foxconntech, and Zhen Ding Tech, which are members of the Foxconn Group. In the end, data on 58 corporations is gathered.

\section{Data collection and analysis}

In terms of data collection, this study performs data gathering and compilation with electronic news data. UDNdata is a database that consolidates data from United Daily News, Economics Daily, Min Sheng Daily, United Evening News, upaper, which are newspapers in the United Group, as well as Business Weekly and Global View magazine [20]. Information retrieved is stored in a self-created database. In the first stage, this study gathered 377,190 sets of data. In the second stage, after using pattern-matching, explanation-building, time-series analysis, and program logic models for analyses, the process yielded 651 sets of data. In the third stage, this study gathered 158 sets of data on transformation with servitization. After applying strategy incident classification, 271 sets of data were produced. Finally, after 12 in-depth interviews with seven experts with more than ten years of industry experience, this study gets four major service strategies.

\section{Result and Discussion}

\section{Servitization transformation strategy}

This study repeatedly speculates the types and implications of servitization in the data of transformation incidents gathered. The structure of the study is based on four major strategy models: 
value-added servitization, differentiation servitization, expansion servitization, and integration servitization. This study further classifies transformation of servitization into 12 categories (including 24 sub-categories in total): A. Customer service after sale, B. Technical service, C. Agency service, D. Internet platform service, E. Green service, F. Value chain consolidation service, G. Terminal market service, H. Technical innovation service, I. Derivative industry-crossing service, J. Industry-crossing support service, K. Comprehensive solution service, and L. Image promotion service.

\section{Servitization strategy distribution analysis}

The purpose of this section is studying the types of strategies for servitization transformation. Based on survey of literature, four strategies for servitization transformation are discovered, which are value-added servitization, differentiation servitization, expansion servitization, and multi-dimensional servitization. Based on their ratio in the whole service incident count, the ranking is as follows: 1. Expansion servitization, with a total number of 86 incidents, making up $31.73 \%$ in the whole service incident count ratio; 2. Differentiation servitization, with a total number of 85 incidents, making up $31.37 \%$ in the whole service incident count ratio; 3 . Value-added servitization, with a total number of 61 incidents, making up $22.51 \%$ in the whole service incident count ratio; and 4. Integration servitization with a total number of 39 incidents, making up $14.39 \%$ in the whole service incident count ratio.

\section{Discussion}

This study is an open-ended research on the data in "manufacturing industry database." By consolidating analysis of data, this study uses servitization as a viewpoint to produce the transformation model that influences the manufacturing industry by servitization. There are four major types, which are further classified into 12 categories (including 24 sub-categories). Through the analysis, we obtain the following findings: Finding 1: Manufacturing firms take the strategies of investing in another industry and supply chain vertical integration as their priority; Finding 2: Derivative industry-crossing service, supply chain vertical integration, web platform service, and technical service are the current development trends of the manufacturing industry; Finding 3: Terminal market service, agency service, image promotion service, cross-industry support service, and green service are more easily ignored by businesses; Finding 4: Computer peripheral and electronics industry of the information and communication technology industries have fewer counts of transformation due to their longer product cycles. Because the computer system industry has a shorter product cycle, it has more cycles of transformation; Finding 5: Businesses tend to use investments in subsidiaries to incorporate vertically integrated companies outside their industry so that they can accomplish supply chain vertical integration or vertical integration outside their industries, and provide system platforms to serve their customers.

\section{Conclusion}

When a business is faced with the process of servitization, it will take the first servitization strategy that crosses the industry boundary but has a lower level of servitization as a priority [14] [10] [15]. From this fact, we can know that value-added service is the direction of decision that most firms will choose when they are transforming for the first time. Expansion servitization is the second most popular choice. When businesses pass the transformation of the first stage, subsequent direction of transformation will be mostly based on differentiation servitization [13] [18] [5] [6].Based on the discussion above, we know that the method of industry transformation will differ according to the nature of management at those businesses.

\section{Management implications and future research}

Based on the findings mentioned earlier, this study offers the following management implications and future research: 
1. "Derivative industry-crossing service" ranks first in overall servitization. Among the options in "derivative industry-crossing service," "investing in a subsidiary across the industry boundary" and "derivative service" are more popular options. They cover a wide range of servitization. Therefore, "derivative industry-crossing service" is one of the focus operations in the application of servitization in businesses. This study suggests that, when manufacturers introduce servitization models, they adopt this type of servitization as priority. However, derivative industry-crossing service requires greater capital input. For small and medium businesses, the government can provide relevant policies and plans and subsidize manufacturers in its implementation.

2. "Market/end-user service," "agency service," "image promotion service," "industry-crossing support service," and "green service" rank lower in overall servitization. It shows that these five services are more easily ignored by businesses. Also, "health exam service," "derivative peripheral product service," "leasing service," and "technical support service" make up $0.74 \%$ of all service innovation incidents each. It is recommended that the government promote servitization options and cooperate with all industries. Although it costs businesses more upfront, however, later on these businesses will have the first entrant advantage and have an easier time in developing untapped markets.

3. "Optoelectronic and semiconductor industry" make up the lowest percentage, with 44 incidents in total. They make up $16.24 \%$ of all servitization incident ratios. It is recommended that businesses in optoelectronics and semiconductor industries and businesses in the application of raw material can increase their extent of servitization and broaden their offering in the services of servitization.

4. "Technical support service" makes up only $0.74 \%$, ranking second to last and presents a great gap from the $11.81 \%$ of "supply chain vertical integration service."The strategy service function in the combination between different industries is the major trend in critical future services.

5. This study finds that the trend of servitization is "implementing investments in another industry by material resources such as capital, plant, equipment, and material to achieve the purposes of supporting vertical integration of supply chain, sales channel, or non-operating income." This study explores transformation strategies of the manufacturing industry from the viewpoint of servitization. It does not investigate corporate performance. Therefore, in the future, such research can incorporate corporate performance research.

\section{References}

[1] Alix, T.\& Zacharewicz, G ,Product-service systems scenarios simulation based on G-DEVS/HLA: Generalized discrete event specification/high level architecture, Computer In Industry 63(4), 2012,370-378.

[2] Barbara, B. \& Philippe, H, Toward a definition of corporate transformation,Sloan Management Review, 35(3), 1994,101-106.

[3] Davies, Andrew, Are Firms Moving 'Downstream' into High-value Servicesin Service Innovation: Organisational responses to technological opportunities and market response, Tidd, J. and Hull, F., eds. London: Imperial College Press,2003.

[4] Hammer, M. and J. Champy, Reengineering the Corporation: A. Manifesto for Business Revolution, New York: Harper Business, 1993.

[5] Homburg, C., \&Garbe, B, Towards an improved understanding of industrial services:quality dimensions and their impact on buyer-seller relationships,Journal of Business-to-Business Marketing (6:2), 1999,pp.39-71.

[6] Jonathan, D. D, Corporate transformation without a crisis, The McKinsey Quarterly, 4, 2000,pp.116-128.

[7] Levy, A. \& U. Merry, Organizational Transformation, New York : Praeger.1986,p26. 
[8] Lightfoot, H. W., Baines, T. and Smart, P, Examining the information and communication technologies enabling servitized manufacture, Proceedings of the Institution of Mechanical Engineers Part B-Journal of Engineering Manufacture,225(B10),2011,pp. 1964-1968.

[9] Mont, Oksana , Product - Service Systems :Panacea or Myth , Doctor Dissertation , Lund University ,2004.

[10] Oliva, R. \&Kallenberg, R, Managing the transition from products to services.International Journal of Service Industry Management, 14(2), 2003,pp.160-172.

[11]Reinartz, W.,Ulaga, W.(2008), How to sell services more profitably.Harvard Business Review,86,2008,pp.90-96.

[12] Shaheen, G. T, Approach to transformation. Chief Executive, March, 1994,pp.2-5.

[13] Slywotsky, A.J. \& Morrison, D.J., (1997), The Profit Zone: How Strategic Business Design Will Lead You to Tomorrow's Profit,Chichester: John Wiley \& Sons.

[14] Sonnenfeld, J. A., \&Peiperl, M. A, Staffing policy as a strategic response: A typology of career systems. Academy of Management Review, 13,1988,pp. 588-600.

[15] Spath, D. and Fahnrich, K. P, Advances in service innovations,2007

[16] Vandermerve, Sandra and Juan Rada, Servitization of Business: Adding Value by Adding Service, European Management Journal, 6 (4), 1988,pp. 314-423.

[17] White, Allen L., Mark Stoughton and Linda Feng, Servicizing: The Quiet Transition to Extended Product Responsibility, U.S. Environmental Protection Agency, Office of Solid Waste,1999.

[18] Wise, R. \& Baumgartner, P, Going downstream: the new profit imperative in manufacturing, Harvard Business Review, September-October.,1999,pp. 133-141.

[19] Yin, R. K, Case study research: Design and methods. Thousand Oaks, CA: Sage,1994.

[20]UDN database http://80-udndata.com.lib1.nkfust.edu.tw/ndapp/Index. 